ISSN 2597- 6052

\title{
Evaluasi Program Tablet Tambah Darah pada Remaja Putri
}

\author{
Fitriana*1, Dhito Dwi Pramardika $^{2}$ \\ ${ }^{1}$ Akademi Kebidanan Bunga Husada samarinda \\ ${ }^{2}$ Politeknik Negeri Nusa Utara \\ Email : fitriana.pramardika90@gmail.com
}

Evaluation of Blood-Tableting Programs in Young Women

\begin{abstract}
Abstrak
Data Riskesdas 2018 menunjukkan bahwa anemia remaja putri adalah 48,9\%, hal Ini akan berdampak buruk pada penurunan imunitas, konsentrasi, prestasi belajar, kebugaran remaja dan produktivitas jika tidak ditangani dengan benar. Puskesmas Bengkuring telah mengimplementasikan program pemberian Tablet Tambah Darah untuk remaja putri selama satu tahun dengan keberhasilan program pada 2018 yaitu 97,1\%. Penelitian ini bertujuan mengevaluasi program tablet tambah darah untuk remaja putri di wilayah kerja Puskesmas Bengkuring. Penelitian ini merupakan penelitian evaluasi dengan metode penelitian kualitatif yang dilakukan pada bulan April hingga Mei 2019 di wilayah kerja Puskesmas Bengkuring. Data kualitatif dianalisis dengan analisis isi. Pada tahap input ada perbedaan dalam fasilitas dan infrastruktur. Pada tahap proses, ketidaksesuaian terjadi dalam distribusi, pemantauan dan pencatatan dan pelaporan. Pada tahap output, ketidakcocokan terjadi dalam penargetan dan ketepatan waktu dan distribusi. Pada tahap hasil ada perubahan dalam pengetahuan. Prevalensi anemia terjadi pada 3 dari 10 gadis remaja. Kesimpulan dari kegiatan ini adalah bahwa pada tahap input, proses, output masih ada ketidaksesuaian dalam implementasinya, sementara hasilnya masih perlu ditingkatkan, dan masih ada gadis remaja yang mengalami anemia.
\end{abstract}

Kata Kunci : Evaluasi, tablet tambah darah, remaja putri.

\begin{abstract}
Data of Riskesdas 2018 shows that teenage girl anemia is 48.9\%, this will adversely affect the decrease in immunity, concentration, learning achievement, youth fitness and productivity if not handled properly. Bengkuring Health Center has implemented a program Blood Adding Tablets (BAT) to teenage girl for one year with the Achievement in 2018 at 97.1\%. This study aims to evaluate the blood adding tablet program for teenage girl. This study is an evaluation research with a qualitative research method conducted in April to May 2019 in the Bengkuring Puskesmas work area. Qualitative data were analyzed by content analysis.At the input stage there are discrepancies in the facilities and infrastructure. At the process stage, nonconformities occur in the distribution, monitoring and recording and reporting. At the output stage, mismatches occur in targeting and timeliness and distribution. At the outcome stage there is a change in knowledge. The prevalence of anemia occurred in 3 out of 10 teenage girl.The conclusion of this activity is that at the input, process, output stage there are still incompatibilities in its implementation, while the outcomes still need to be improved, and there are still teenage girl who are anemic.
\end{abstract}

Keywords : Evaluation, Blood Adding Tablet, Teenage girl. 


\section{PENDAHULUAN}

Anemia merupakan salah satu dari 6 masalah gizi yang ada di Indonesia saat ini. Berdasarkan hasil Riskesdas (2018) proporsi anemia ibu hamil sebesar $46,9 \%$ dan anemia remaja sebesar 48,9\%. Berdasarkan hal tersebut anemia lebih banyak dialami pada remaja (1).

Remaja perempuan merupakan kelompok usia yang paling banyak membutuhkan zat gizi dibanding kelompok usia lainnya. Pematangan seksual pada remaja menyebabkan kebutuhan zat gizi meningkat. Kebutuhan zat besi remaja perempuan lebih tinggi dibandingkan dengan remaja laki-laki, karena dibutuhkan untuk mengganti zat besi yang hilang pada saat menstruasi (2).

Anemia pada remaja berdampak buruk terhadap penurunan imunitas, konsentrasi, prestasi belajar, kebugaran remaja (3). Kesehatan remaja sangat menentukan keberhasilan dari pembangunan kesehatan, terutama dalam upaya mencetak kualitas generasi penerus bangsa di masa depan. mengingat mereka adalah para calon ibu yang akan hamil dan melahirkan seorang bayi, sehingga memperbesar risiko kematian ibu melahirkan, bayi lahir prematur dan berat bayi lahir rendah (BBLR) (4).

Oleh karena itu Pemerintah Indonesia berupaya untuk mengatasi hal tersebut yang tertuang dalam RPJMN 2015-2019 yaitu pada sasaran pokok yang pertama berupa meningkatnya status kesehatan ibu dan Anak. Usaha yang dilakukan pemerintah indonesia yaitu melalui usaha kesehatan sekolah dan remaja (5).

Salah satu program pemerintah yaitu pemberian Tabet Tambah Darah (TTD) pada remaja puteri. Berdasarkan hasil Riskesdas (2018) bahwa Remaja puteri yang mendapatkan tablet tambah darah (TTD) sebesar $76,2 \%$ yang terdiri dari sebanyak $80,9 \%$ diantaranya mendapatkan TTD di sekolah dan 19,1\% menyatakan tidak didapatkan dari sekolah. Sedangkan yang tidak mendapatkan TTD sama sekali yaitu sebesar $23,8 \%$. Tingkat konsumsi TTD yang $<52$ butir sebesar $98,6 \%$ dan yang mengkonsumsi $\geq 52$ butir sebesar $1,4 \%$.

Remaja putri diharuskan untuk mengkonsumsi TTD karena mengalami menstruasi setiap bulan. TTD juga berguna untuk mengganti zat besi yang hilang karena menstruasi dan untuk memenuhi kebutuhan zat besi yang belum tercukupi dari makanan. Zat besi pada remaja putri juga bermanfaat untuk meningkatkan konsentrasi belajar, menjaga kebugaran dan mencegah terjadinya anemia pada calon ibu di masa mendatang (4).

Di Puskesmas Bengkuring sendiri program ini sudah dilaksanakan sejak tahun 2018, hingga tahun 2019 saat ini. TTD ini dibagikan pada 9 SMP dan 8 SMA yaitu sebanyak 1.799 siswi. Pada tahun 2018 persentase capaian TTD yang diberikan kepada remaja puteri sebesar $97,1 \%$. Pencapaian yang tinggi dari sasaran yang telah ditetapkan oleh Puskesmas Bengkuring yang hanya sebesar 20\%. Kemudian selama 1 tahun lebih, kegiatan ini juga belum pernah dilakukan evaluasi terhadap program ini (6). Berdasarkan hal tersebut, penelitian ini bertujuan untuk mengevaluasi evaluasi program tablet tambah darah (TTD) pada remaja puteri di wilayah kerja UPT Puskesmas Bengkuring tahun 2019.

\section{METODE}

Penelitian ini dilaksanakan pada tanggal 1 April 2019 sampai dengan 31 Mei 2019. Penelitian ini merupakan Evaluation research dengan menggunakan metode penelitian kualitatif. Penelitian kualitatif dilakukan berupa indepth interview kepada 2 remaja puteri, 1 guru UKS dan 1 petugas gizi Puskesmas. Kemudian data dari indepth interview tersebut dianalisis dengan menggunakan content analysis.

Sementara penelitian kuantitatif yang dilakukan yaitu dengan melakukan pemeriksaan kadar Hemoglobin $(\mathrm{Hb})$ darah pada remaja Puteri dengan menggunakan alat HB digital dengan merk Easy Touch sebanyak 45 remaja puteri dari 2 kelurahan di wilayah kerja Puskesmas Bengkuring yaitu SMKN 16 Kelurahan Sempaja Timur dan SMKN Pelayaran Kelurahan Sempaja Utara yang diambil dengan menggunakan purpossive sampling, yang kemudian data tersebut akan dianalisis dengan menggunakan triangulasi sumber.

\section{HASIL}

UPT Puskesmas Bengkuring merupakan salah satu dari 26 Puskesmas yang berada di Kota Samarinda dengan luas wilayah $\pm 60,29 \mathrm{~km}^{2}$ yang terdiri dari 2 kelurahan yaitu Kelurahan Sempaja Timur dan Kelurahan Sempaja Utara. Puskesmas Bengkuring merupakan Puskesmas dengan akreditasi Madya pada tahun 2018. Jumlah pegawai sebanyak 48 orang. Puskesmas Bengkuring memiliki 9 Sekolah Menengah Pertama (SMP) atau sederajat dan 8 Sekolah Menengah Atas (SMA) atau sederajat.

\section{Karakteristik Partisipan}

Jumlah partisipan dalam penelitian ini sebanyak 4 orang dengan inisial nama pertama W.A.H usia 53 tahun jabatan nutrisionis sebagai partisipan kunci, inisial nama kedua W.B.A usia 16 tahun jabatan siswi sebagai partisipan utama, inisial nama ketiga W.B.S usia 16 tahun jabatan siswi sebagai partisipan utama, dan yang keempat inisial W.C.M usia 47 tahun jabatan guru UKS sebagai partisipan tambahan. 


\section{Deskripsi Input}

\section{Sumber Daya Manusia}

Berdasarkan hasil penelitian bahwa Pada program pemberian tablet tambah darah (TTD) ini sudah terintegrasi dengan program yang lain. Sumber daya yang terlibat meliputi dari Bagian Administrasi manajemen yang terdiri dari 2 orang tenaga (Kasub Bag Tata Usaha dan petugas administrasi) bertanggung jawab pada pembuatan Surat Keputusan (SK) Tim TTD, pembuatan surat menyurat, pengumpulan laporan serta pertanggung jawaban keuangan dari pelaksanaan program ini.

Kemudian Bagian Upaya Kesehatan Masyarakat (UKM). Gizi masyarakat yang termasuk dalam kegiatan Upaya Kesehatan masyarakat (UKM) luar gedung bertanggung jawab terhadap pelaksanaan program ini. Sumber daya yang terlibat sebagai koordinator ini ada 2 orang nutrisionis yang bertanggung jawab terhadap penerimaan, penyimpanan, penyusunan jadwal Distribusi, pelaporan dan evaluasi. Pelaksanaan distribusi dilakukan oleh 4 tim, 1 tim terdiri dari 2 orang per sekolah.

Bagian Upaya Kesehatan perorangan (UKP).Upaya kesehatan perorangan terdiri dari tenaga medis dan para medis yang bertanggung jawab pada remaja puteri yang mengalami dampak dari konsumsi TTD yang diberikan oleh Puskesmas di sekolah. Hal ini sesuai dengan kutipan pernyataan wawancara yang disampaikan oleh partisipan kunci sebagai berikut : Kutipan 1 "ee.. kalo sumber daya, TTD ni ga bisa kerja sendiri. Harus kerja tim. Kalo Admen yang suratmenyurat trus tempat kumpul laporan. Trus kalo saya ni di UKM sebagai yang buat jadwal dan siapin obatnya untuk diberikan ke tim yang bagi ke sekolah, jumlah tim ada empat, satu tim itu ada dua orang per sekolah yang bagikan TTD. Trus kalo ada apa-apa dengan siswinya itu dirujuk ke puskesmas untuk ditangani tim UKP. Jadi banyak orang yang dilibatkan cuman kalo yang bertanggung jawab sama program ini itu saya e dibantu dengan satu orang teman saya, orang gizi juga. Karena TTD ini, itu kegiatan gizi" W.A.H.11

Hal ini diperkuat dari pernyataan partisipan tambahan sebagai berikut :Kutipan 2 "Pembagian obatnya tu biasanya ada dua orang puskesmas nganter trus datang ke UKS sini. Saya yang nerima" W.C.M.7

\section{Alokasi Dana}

Berdasarkan hasil penelitian bahwa TTD yang diperoleh berasal dari Dinas Kesehatan Kota Samarinda. Namun untuk alokasi dana distribusi TTD kepada remaja Puteri di wilayah kerja Puskesmas Bengkuring itu menggunakan Dana Alokasi Khusus Kesehatan (DAK) BOK tahun 2018 berupa biaya transportasi petugas sebesar Rp. 6.750.000,-. Dan pada tahun 2019 ini untuk TTD sebesar Rp. 12.240.000,-.

Hal ini sesuai dengan kutipan pernyataan wawancara oleh partisipan kunci sebagai berikut : Kutipan 3 "e.. alokasi dana apa ya? Kalo TTD tu gratis, kami ga beli tapi dikasih dari Dinas Kesehatan Kota Samarinda. Tapi kalo kita bagi-bagi ke sekolahnya itu baru ada biayanya, biaya transportasi petugas ke sekolah gitu ceritanya dari dana BOK" W.A.H.15.

Kutipan 4 "sebentar ku liat dulu ya, emm.. total anggaran TTD untuk tahun dua ribu delapan belas kemaren sebesar enam juta tujuh ratus lima puluh ribu, trus kalo tahun ini TTD di anggarkan dua belas juta dua ratus empat puluh ribu” W.A.H.16

\section{Sarana dan Pra sarana}

Berdasarkan hasil penelitian bahwa sarana dan pra sarana hanya tersedia di tahun 2018 berupa brosur, leaflet untuk kegiatan sosialisasi serta remaja puteri diberikan kartu suplementasi TTD. Namun pada tahun 2018, tidak disediakan lagi oleh Dinas Kesehatan Kota Samarinda dan UPT Puskesmas Bengkuring. Sarana yang digunakan hanya berupa plastik untuk mengemas TTD, kamera smart phone milik setiap pribadi dari tim pelaksana TTD yang digunakan untuk kegiatan dokumentasi. Grup Whats App (WA) Guru UKS dan Grup WA Puskesmas Bengkuring sebagai sarana informasi pelaksanaan program TTD.

Hal ini sesuai dengan kutipan pernyataan wawancara sebagai berikut : Kutipan 5 "tahun kemaren tu ada kita dikasih brosur, leaflet dengan kartu minum TTD, trus tahun ini ga ada dapat lagi. Sarana yang digunakan ee.. plastik untuk bawa TTDnya ke sekolah trus juga bawa hp sendiri buat poto-poto untuk SPJnya. Trus klo ada apa-apa kita kasih info di WA guru UKS dan WA puskesmas bengkuring" W.A.H.19

\section{Desksripsi Proses \\ Persiapan}

Berdasarkan hasil penelitian bahwa tahap persiapan di awali sebagai berikut : Perhitungan sasaran dari TTD remaja puteri berdasarkan data jumlah Siswi SMP dan SMA di wilayah kerja x 52 tablet dan ditambahkan $10 \%$ buffer stok, Penyusunan kepanitiaan yang kemudian ditetapkan melalui SK kepala Puskesmas, Penyusunan Standar Operasional Prosedur (SOP) mengenai pemberian TTD, Penyusunan jadwal pelaksanaan kegiatan, Menginformasikan kepada pihak sekolah melalui surat tentang jadwal kegiatan TTD.

Hal ini sesuai dengan kutipan pernyataan wawancara sebagai berikut : Kutipan 6 "persiapannya yang pertama tu dimulai dulu dari menghitung jumlah sasaran berdasarkan buku panduan TTD dari 
kemenkes yaitu dari data jumlah siswi di SMP dan SMA dikalikan lima puluh dua tablet kemudian ditambahkan sepuluh persen untuk stok. Trus yang kedua, membuat panitia yang di SK kan oleh pimpus. Yang ketiga, buat SOP juga trus yang terakhir tu baru kita susun jadwal dari tim panitia dan kirim surat ke semua sekolah kalo mau melaksanakan TTD" W.A.H.23.

\section{Pendistribusian}

Berdasarkan hasil penelitian bahwa pendistribusian dilakukan dengan cara blanket approach yang dibagikan oleh tim setiap bulannya sebanyak 4 tablet per siswi dengan jumlah minum TTD sebanyak 1 tablet untuk 1 minggu.

Hal itu sesuai dengan kutipan pernyataan wawancara sebagai berikut : Kutipan 7 "TTD yang dibagikan ke siswi itu sebanyak empat tablet untuk satu bulan. Ee... Sekali minum itu satu tablet untuk satu minggu. Biasanya kami suruh minumnya malam aja pas mau tidur" W.A.H.25.

Pelaksanaan distribusi TTD dilakukan tiap minggu pertama sampai dengan minggu kedua tiap bulannya. Jumlah sekolah sebanyak 17 sekolah, jadi satu hari bisa 2 sekolah yang didistribusikan sesuai dengan jadwal. Petugas menyerahkan TTD kepada guru UKS yang kemudian akan dibagikan kepada siswi di sekolahnya.

Hal itu sesuai dengan kutipan pernyataan wawancara sebagai berikut : Kutipan 8 "ceritanya tu kayak gini nah, tiap bulannya tu TTD dibagikan ke sekolah setiap minggu pertama sampai minggu ke dua. Jadi per harinya tu bisa dua atau tiga sekolah gitu yang didatangi. Kemudian TTDnya tu dikasihkan aja ke Guru UKSnya, biar gurunya yang bagi jadi cepat kita selesai" W.A.H.29.

Hal ini diperkuat dari pernyataan partisipan utama sebagai berikut Kutipan 9 "iya pak, kami dapat obatnya ni tiap awal bulan, dikasih sama ibu guru" W.B.A.7.

\section{Pemantauan}

Berdasarkan hasil penelitian bahwa pemantauan TTD ini hanya berupa pelaporan data dari petugas pelaksana tiap bulannya. Data tersebut berasal dari pernyataan dari guru UKS saja mengenai jumlah TTD yang telah didistribusikan.

Hal ini sesuai dengan kutipan pernyataan wawancara sebagai berikut : Kutipan 10 "ee.. kalo pemantauan dilaksanakannya setiap kita ngasih obat tu ke guru UKS, sekalian lah kita tanya ke gurunya, berapa sudah yang dibagikan? Biasanya sih abis tiap bulannya. Jadi bulan depan juga dikasih dengan jumlah yang sama seperti itu” W.A.H.33.

Hal ini diperkuat dari pernyataan partisipan tambahan sebagai berikut : Kutipan 11 "biasanya pak, mereka datang tiap bulan ngasih obatnya sekalian nanya jumlah yang udah saya kasih ke siswi, baru dengan bapak ini siswi kami diperiksa darahnya" W.C.M.15.

\section{Pencatatan dan Pelaporan}

Berdasarkan hasil penelitian bahwa pencatatan dan pelaporan TTD dilaksanakan tiap bulannya dan dilaporkan kepada tim administrasi manajemen dan Dinas Kesehatan kota Samarinda.

Hal itu sesuai dengan kutipan pernyataan wawancara sebagai berikut : Kutipan 12 "Laporan rutin tiap bulannya dilaporkan ke admen dan ke dinas. Telat sedikit aja sudah saya sampaikan di apel pagi" W.A.H.37.

Pencatatan TTD dari guru UKS hanya berupa jumlah obat yang diterima dan hanya dilaporkan kepada puskesmas melalui verbal. Hal itu sesuai dengan kutipan pernyataan wawancara dari partisipan tambahan sebagai berikut : Kutipan 13 "biasanya kami catat pak, obat yang kami terima trus kami ga buat laporan cuma kami kasih tau aja kepada orang puskesmas klo obatnya udah kami kasihkan" W.C.M.18

\section{Deskripsi Output \\ Cakupan Kegiatan}

Berdasarkan hasil penelitian bahwa cakupan kegiatan pada program TTD tahun 2018 di UPT Puskesmas Bengkuring adalah sebesar 97,1\%. Hal itu berdasarkan jumlah obat yang diterima setiap bulannya pada remaja puteri wilayah kerja Puskesmas Bengkuring yang dimulai sejak bulan maret 2018 hingga bulan Desember 2018. Capaian tidak 100\% dikarenakan sasaran lagi mengikuti kegiatan ekstrakurikuler di luar kota.

Hal itu berdasarkan dari kutipan pernyataan wawancara sebagai berikut : Kutipan 14 "TTD ini udah dilaksanakan mulai dari bulan maret sampe bulan Desember dua ribu delapan belas. Tahun ini pun juga dilaksanakan. Kalo capaian TTD tahun dua ribu delapan belas itu sebesar sembilan puluh tujuh koma satu persen dari sasarannya dua puluh persen. Angka itu didapat dari jumlah TTD yang diberikan kepada remaja puteri di sekolah. Tidak seratus persen dikarenakan ada beberapa bulan sasaran lagi mengikuti pesantren di luar daerah" W.A.H.40.

\section{Ketepatan sasaran, waktu dan distribusi}

Berdasarkan hasil penelitian bahwa sasaran pada program TTD ini yaitu remaja puteri dari kelas 1 SMP hingga kelas 3 SMA. Hal itu sesuai dengan kutipan pernyataan wawancara sebagai berikut : Kutipan 15 "yang menerima TTD ni ya murid perempuan dari kelas satu SMP hingga kelas tiga SMA"W.A.H.43. 
Ketepatan waktu pada program TTD ini berupa waktu konsumsi dan waktu pelaksanaan distribusi TTD. Waktu konsumsi TTD di rumah yaitu sesudah makan malam dan sebelum tidur. Hal itu sesuai dengan kutipan pernyataan wawancara sebagai berikut : Kutipan 16 "emm.. waktu minumnya di rumah setelah makan malam, abis itu baru minum obatnya sebelum tidur" W.B.S.30

Sedangkan waktu pelaksanaan distribusi, disesuaikan dengan kalender pendidikan. Jika berdekatan dengan hari libur maka diberikan TTD dengan jumlah lebih dari biasanya. Hal itu sesuai dengan kutipan pernyataan wawancara sebagai berikut : Kutipan 17 "Kami susun jadwal itu sesuai dengan kalender pendidikan. Misal ni ya, kalo mau libur kayak mau lebaran kemaren ini, kami siapin sekalian untuk 2 bulan biar ga terputus" W.A.H.47

\section{Deskripsi Outcome \\ Efek atau dampak}

Berdasarkan hasil penelitian bahwa efek atau dampak dari TTD yang dialami oleh remaja puteri setelah mengkonsumsinya yaitu mual, muntah dan pusing. Hal itu sesuai dengan kutipan pernyataan wawancara sebagai berikut : Kutipan 18 "saya pernah pak, dulu pertama kali minum obatnya ngerasa mual, muntah dan pusing" W.B.S.30. Hal itu diperkuat dengan pernyataan kutipan wawancara dari partisipan kunci sebagai berikut : Kutipan 19 "iya, dulu tu ada laporan sekolah yang muntah-muntah seteleh mereka minum obat. Itu tu karena mereka belum makan. Tapi sekarang TTD yang diberikan beda dengan yang tahun lalu merknya Tablet tambah darah dari Kimia Farma, yang ini rasanya manis, sebentar saya liatkan nama obatnya dulu. Oh ini dia, nama merknya Hemafort dari Phapros. mereka suka dan udah ga ada lagi keluhan kayak kemaren” W.A.H.52

Namun program TTD ini juga mendapat manfaat yang baik seperti keluhan nyeri haid berkurang dan lebih bugar ketika mengkonsumsi TTD. Kutipan 19 "sejak ada program bagi vitamin ini, siswinya udah jarang yang mengeluhkan sakit perut, lemes saat datang bulan, kemudian anak-anak terlihat lebih segar" W.C.M.26

\section{Deskripsi Prevalensi Anemia}

Berdasarkan hasil pemeriksaan yang dilakukan kepada remaja puteri diperoleh data bahwa 3 dari 10 remaja puteri mengalami anemia.

\section{PEMBAHASAN \\ Input}

Berdasarkan hasil penelitian diketahui bahwa evaluasi input pada program TTD pada remaja Puteri di Puskesmas Bengkuring berupa Sumber daya manusia, alokasi dana dan sarana pra sarana bahwa sarana dan pra sarana untuk menunjang program ini masih kurang seperti Brosur, leaflet dan kartu suplementasi TTD. Media brosur dan leaflet sangat diperlukan untuk meningkatkan pengetahuan karena didalam media tersebut terdapat informasi mengenai TTD dan anemia. Hal itu sesuai yang menyatakan bahwa Informasi yang diperoleh dapat memberikan landasan kognitif (7).

Pada penelitian Putri, dkk (2017) menyatakan bahwa tingkat pengetahuan gizi yang kurang mempunyai peluang sebesar 3,951 kali mengalami kejadian anemia dibandingkan dengan remaja puteri yang mempunyai tingkat pengetahuan gizi yang baik (8).

Sedangkan kartu suplementasi TTD juga sangat diperlukan sebagai alat untuk menumbuhkan kesadaran dan kedisiplinan bagi remaja puteri karena kartu suplementasi TTD dianggap sebagai pekerjaan rumah oleh guru UKS. Hal itu sesuai dengan Arikunto (2008) yang menyatakan bahwa mengerjakan tugas sekolah merupakan salah satu dari tujuh indikator kedisiplinan (9).

Kartu suplementasi ini mempunyai hubungan yang bermakna seperti halnya penelitian yang dilakukan oleh Waliyo dan Agusanty (2015) yang menyatakan terdapat perbedaan rata-rata jumlah tablet yang diminum oleh ibu hamil pada kelompok yang diberi kartu pemantauan minum TTD dengan kelompok kontrol $(p=0,002)$ [12]. Sedangkan pada remaja puteri dalam penelitian Nuradhiani (2017) yang menyatakan bahwa kelompok kartu monitoring dengan penambahan tanda tangan orang tua dan guru memiliki tingkat kepatuhan yang tinggi dibandingkan dengan kartu monitoring dari Dinas Kesehatan ataupun kartu monitoring berupa leaflet (10).

Minimnya kegiatan input dalam program TTD di Puskesmas Bengkuring ini sejalan dengan penelitian yang telah dilakukan oleh Hurfiati yang menyatakan bahwa indikator input meliputi dana, tenaga, sarana belum mencukupi kebutuhan program sedangkan ketersediaan TTD sudah mencukupi (11).

\section{Proses}

Berdasarkan hasil penelitian diketahui bahwa ada 4 tahap yang dinilai yaitu tahap persiapan, tahap distribusi, tahap pemantauan, tahap pencatatan dan pelaporan. Keempat tahapan tersebut apabila dilakukan dengan sesuai Standar Operasional Prosedur (SOP) yang telah ditetapkan oleh Puskesmas Bengkuring maka akan dapat meningkatkan cakupan capaian program dari kegiatan TTD ini.

Namun dalam teknis pelaksanaannya masih terdapat ketidaksesuaian yaitu Puskesmas Bengkuring melakukan distribusi TTD 1 kali setiap bulan. Hal ini tidak sesuai karena berdasarkan buku pedoman 
pencegahan dan penanggulangan anemia pada remaja putri dan wanita usia subur (WUS) (2016) yang menyatakan bahwa TTD diberikan di sekolah setiap minggu [3]. Puskesmas Bengkuring melakukan hal tersebut dikarenakan lebih efisien dalam segi waktu.

Pada tahap pemantauan juga masih belum sesuai karena petugas hanya bertanya jumlah TTD yang diberikan. Seharusnya yang dilakukan adalah pemantauan kepatuhan remaja puteri mengkonsumsi TTD dan perlu dilakukan pemantauan dari kadar hemoglobin darah minimal 6 bulan sekali.

Pada tahap pencatatan dan pelaporan dilakukan setiap bulannya kepada Dinas Kesehatan Kota Samarinda melalui laporan gizi. Hal ini merupakan kinerja program yang baik karena berdasarkan buku pedoman pencegahan dan penanggulangan anemia pada remaja putri dan wanita usia subur (WUS) (2016) yang menyatakan bahwa pelaporan dilakukan setiap 3 bulan sekali. Pada tahap pelaporan, untuk meningkatkan capaian program TTD di bulan berikutnya, harus disertakan juga analisis dari permasalahan dalam proses kegiatan tersebut serta feed back kepada pihak terkait seperti sekolah dan dinas kesehatan Kota Samarinda.

Pada tahap pencatatan disini bukan hanya menjadi tanggung jawab dari petugas Puskesmas namun juga keterlibatan dari pihak sekolah berupa pemantauan pencatatan kartu suplementasi TTD dan pencatatan ke dalam buku rapor kesehatan, karena sejak tahun 2015 semua peserta didik telah memiliki buku rapor kesehatan yang dikeluarkan oleh Kementerian kesehatan Republik Indonesia.

Kegiatan pencatatan dan pelaporan merupakan fungsi dan wewenang yang wajib dilakukan berdasarkan Permenkes No. 75 tahun 2014 untuk mewujudkan pembangunan kesehatan di wilayah kerja Puskesmas.

Pada tahap proses dari program TTD Puskesmas Bengkuring masih terdapat ketidaksesuaian dengan pedoman dari tahap distribusi, tahap pemantauan, tahap pencatatan dan pelaporan. Hal itu juga dialami pada penelitian yang dilakukan oleh Hurfiati yang menyatakan bahwa Indikator proses meliputi perencanaan kebutuhan, distribusi, cara pemberian, pencatatan, pelaporan dan pemantauan program pemberian TTD belum sesuai dengan petunjuk teknis program pemberian TTD yang dirancang oleh Kementerian Kesehatan (11).

\section{Output}

Berdasarkan hasil penelitian bahwa output berupa cakupan kegiatan dan ketepatan sasaran, waktu dan distribusi program TTD di wilayah kerja Puskesmas Bengkuring masih terdapat beberapa hal yang belum sesuai dengan pedoman.
Cakupan kegiatan dalam hal ini, taget tidak sesuai. Target capaian mengacu pada rencana strategi Direktorat Gizi Masyarakat yang menyatakan bahwa tahun 2015 sebesar 10\%, tahun 2016 sebesar 15\%, tahun 2017 sebesar 20\%, tahun 2018 sebesar $25 \%$ dan tahun 2019 sebesar 30\%. Sementara target yang ditetapkan Puskesmas Bengkuring dari tahun 2018 dan 2019 sebesar $20 \%$.

Ketepatan sasaran Puskesmas Bengkuring sudah sesuai yaitu remaja puteri dari kelas 1 SMP atau sederajat hingga kelas 3 SMA atau sederajat karena berdasarkan Surat Edaran Direktorat Jenderal Kesehatan Masyarakat dengan nomor HK.03.03/V/0595/2016 bahwa yang menjadi sasaran TTD ini adalah Remaja putri usia 12-18 tahun. TTD tidak boleh diberikan pada remaja puteri yang mengalami penyakit, seperti thalasemia, hemosiderosis, atau atas indikasi dokter lainnya [3].

Terdapat ketidaksesuaian mengenai Ketepatan waktu. Dalam hal ini yaitu waktu konsumsi TTD yang dilakukan di rumah masing masing dan pada malam hari. Kegiatan konsumsi TTD masing-masing tersebut kurang efektif dalam hal pemantauan dan menurut peneliti, apabila dilakukan secara bersama di sekolah maka akan menimbulkan kebersamaan dan menjadikan perilaku yang sehat.

Hal itu sesuai dengan Notoatmodjo (2012) yang menyatakan bahwa faktor situasional yang mencakup lingkungan di mana manusia itu bertempat tinggal, baik itu lingkungan fisik, sosial, budaya, ekonomi dan politik dapat mempengaruhi perilaku seseorang (7).

\section{Outcome}

Berdasarkan hasil penelitian bahwa outcome dari program TTD ini berupa efek atau dampak yaitu penggantian jenis TTD dari tahun 2018 berupa tablet tambah darah (kimia Farma) menjadi hemafort (phapros) tahun 2019 yang lebih disukai oleh remaja puteri dikarenakan rasanya yang lebih manis dapat meningkatkan kepatuhan remaja puteri dalam mengkonsumsi TTD.

Upaya untuk meningkatkan kepatuhan konsumsi TTD tersebut juga harus melibatkan dukungan dari guru. Hal itu dibuktikan dalam sebuah penelitian yang dilakukan oleh Nuradhianai, dkk (2017) yang menyatakan bahwa dukungan guru berpeluang 4,7 kali lipat meningkatkan kepatuhan dalam konsumsi Tablet Tambah Darah dibandingkan dengan tidak adanya dukungan dari guru (12).

Perubahan perilaku dari remaja puteri yang terlihat lebih segar merupakan dampak yang baik dari program TTD ini. Hal itu sesuai dengan Dieny (2014) yang menyatakan bahwa program TTD melalui peningkatan zat besi pada remaja putri juga bermanfaat untuk meningkatkan konsentrasi belajar, menjaga 
kebugaran dan mencegah terjadinya anemia pada calon ibu di masa mendatang (4).

Berdasarkan hasil outcome masih berupa jangka pendek yaitu pada tingkat pembelajaran yang meliputi kesadaran, pengetahuan, sikap. Hasil outcome tersebut diharapkan berlanjut hingga jangka menengah dan mempunyai dampak jangka panjang seperti Remaja tersebut nantinya jadi seorang ibu hamil yang bebas dari anemia dan melahirkan bayi yang sehat.

\section{Anemia}

Berdasarkan hasil penelitian bahwa 3 dari 10 remaja puteri di wilayah kerja Puskesmas Bengkuring mengalami anemia. Hal ini dikarenakan rendahnya asupan zat besi. Menurut peneliti, rendahnya asupan zat besi tersebut dikarenakan kurangnya pengetahuan remaja puteri terhadap makanan yang kaya akan zat besi dan makanan yang dapat menghambat penyerapan zat besi. Kurangnya pengetahuan tersebut karena hanya pada tahun 2018 awal saja remaja puteri tersebut mendapatkan sosialisasi mengenai anemia dan TTD.

Hal itu sesuai dengan pernyataan Notoatmojdo (2012) yang menyatakan bahwa pengetahuan atau kognitif merupakan domain yang sangat penting dalam membentuk tindakan seseorang (over behaviour) karena dari pengalaman penelitian terbukti bahwa perihal yang didasari oleh pengetahuan lebih langgeng daripada perilaku yang tidak didasari oleh pengetahuan

Masih terdapatnya kasus anemia sementara remaja puteri tersebut sudah mendapatkan tablet tambah darah merupakan permasalahan yang perlu ditangani. Hal tersebut juga dialami pada penelitian yang dilakukan Permatasari (2018) yang menyatakan bahwa program pemberian TTD pada remaja puteri belum terlalu efektif dalam mengatasi permasalahan anemia. Hal ini dibuktikan dengan prevalensi anemia $(\mathrm{Hb}<12 \mathrm{~g} / \mathrm{dl})$ sebelum program $20.7 \%$ dan menurun menjadi $15.2 \%$ setelah 4 bulan intervensi. Hasil studi eksperimental yang dilakukan Briawan (2008) mengenai suplementasi besi menunjukkan bahwa perubahan dari kadar $\mathrm{Hb}$ pada remaja wanita hanya dipengaruhi $\mathrm{Hb}$ awal (14). Kemudian pada penelitian yang berbeda oleh Briawan juga menyatakan bahwa program suplementasi besi yang dilakukan di Kota Bekasi pada siswi SMP dan SMA, tidak terjadi peningkatan kadar $\mathrm{Hb}$ setelah diberikan suplementasi (15).

\section{KESIMPULAN}

Berdasarkan hasil penelitian didapatkan kesimpulan sebagai berikut : Kurangnya sarana dan prasarana dalam hal media sosialisasi anemia dan TTD seperti brosur dan leaflet, kartu suplementasi TTD dan kamera. Ketidaksesuaian waktu distribusi yang dilakukan 1 kali setiap bulan oleh Puskesmas Bengkuring. Ketidaksesuaian pemantauan program
TTD berupa tidak dilakukan pemantauan kepatuhan konsumsi TTD dan pemantauan kadar hemoglobin darah $(\mathrm{Hb})$ pada remaja puteri. Tidak dilakukannya pencatatan ke dalam buku raport kesehatanku oleh pihak sekolah terhadap program TTD ini. Tidak dilakukannya analisis dan tindak lanjut dan umpan balik dari pelaporan program TTD baik dari pihak sekolah, Puskesmas dan Dinas Kesehatan Kota Samarinda. Ketidaksesuaian target dari sasaran program TTD Puskesmas terhadap rencana strategi direktorat gizi masyarakat. Konsumsi TTD tidak dilakukan secara bersama-sama di Sekolah melainkan di rumah masing-masing. Penggantian Obat Tablet Tambah Kimia Farma (2018) menjadi Hemafort phapros (2019) membuat remaja puteri lebih menyukainya program TTD ini. Remaja puteri terlihat lebih bugar dan keluhan nyeri saat menstruasi berkurang. Sebanyak 3 dari 10 remaja puteri di wilayah kerja UPT Puskesmas Bengkuring mengalami anemia.

Penelitian ini diharapkan dapat dijadikan masukan terhadap Program TTD seperti pemenuhan sarana prasarana, peningkatan sosialisasi atau penyuluhan kesehatan, pemantauan 2 kali dalam setahun untuk pemeriksaan hemoglobin $(\mathrm{Hb})$ darah, pemantauan kepatuhan TTD, membuat analisis, tindak lanjut dan feed back, serta pelaksanaan kegiatan yang berdasarkan buku pedoman yang ada. Bagi Institusi Pendidikan Penelitian ini diharapkan sebagai bahan evaluasi terhadap pelaksanaan program kesehatan di institusi pendidikan seperti mengisi buku raport kesehatanku, mengadakan minum TTD bersama di sekolah, mengaktifkan kegiatan PKPR dan konseling remaja. Bagi peneliti selanjutnya diharapkan sebagai referensi seperti pengembangan metode peningkatan kepatuhan TTD.

\section{DAFTAR PUSTAKA}

1. RI KK. Hasil utama riskesdas 2018. Jakarta Kemenkes RI. 2018;

2. Hunt JR. Bioavailability of iron, zinc, and other trace minerals from vegetarian diets. Am J Clin Nutr. 2003;78(3):633S-639S.

3. Indonesia KKR. Pedoman pencegahan dan penanggulangan anemia pada remaja putri dan wanita usia subur (WUS). Direktorat Gizi Masyarakat, Direktorat Jenderal Kesehat Masyarakat, Kementeri Kesehat Republik Indones Jakarta. 2016;

4. Dieny FF. Permasalahan gizi pada remaja putri. Yogyakarta Graha Ilmu. 2014;7-9.

5. Indonesia KKRI. Rencana strategis kementerian kesehatan tahun 2015-2019. 2015;

6. RI BD, KESEHATAN BP. Manajemen Puskesmas. Jakarta: Departemen Kesehatan RI; 2004.

7. Notoatmodjo S. Promosi kesehatan dan ilmu 
perilaku. Jakarta: Rineka Cipta. 2007;20.

8. Putri RD, Simanjuntak BY, Kusdalinah K. Pengetahuan Gizi, Pola Makan, dan Kepatuhan Konsumsi Tablet Tambah Darah dengan Kejadian Anemia Remaja Putri. J Kesehat. 2017;8(3):404-9.

9. Wardani I. Penelitian tindakan kelas. 2014;

10. Waliyo E, Agusanty SF. Uji coba kartu pemantauan minum tablet tambah darah $(\mathrm{Fe})$ terhadap kepatuhan konsumsi ibu hamil. J Vokasi Kesehat. 2016;2(1):84-8.

11. Shanti KM, Maitri AK, Rosselo J, Destriyani D, Friday LC, Novriana R. Evaluasi Program Pemberian Tablet Tambah Darah (TTD) sebagai Upaya Preventif dan Kuratif Anemia Ibu Hamil di Puskesmas Kraton Kota Yogyakarta. Ber Kedokt Masy. 33(5).

12. Nuradhiani A, Briawan D, Dwiriani CM. Dukungan guru meningkatkan kepatuhan konsumsi tablet tambah darah pada remaja putri di Kota Bogor. J Gizi dan Pangan. 2018;12(3):153-60.

13. Fitriana FF. POLA MENSTRUASI DENGAN KEJADIAN ANEMIA REMAJA DI AKBID BUNGA HUSADA SAMARINDA TAHUN 2017. Mahakam Midwifery J. 2017;2(1):23-32.

14. Briawan D, Setiawan B, Marliyati SA. Efikasi Suplemen Besi-multivitamin Untuk Perbaikan Status Besi Remaja Wanita. Gizi Indones. 2007;30(1).

15. Briawan D, Adriyani A, Pusporini P. Determinan keberhasilan program suplementasi zat besi pada siswi sekolah. J Gizi Klin Indones. 6(2):78-83. 